\title{
Supplementation of fungal and/or bacterial phytase in broiler diets formulated with reduced phosphorus level and different calcium contents
}

\author{
Nicole Batelli de Souza Nardelli' ${ }^{1}$, Luciana de Paula Naves² iD, David Henrique de Oliveira', \\ Antonio Amandio Pinto Garcia Junior ${ }^{1}$, Eduardo Machado Costa Lima ${ }^{1}$, Evelyn Cristina de \\ Oliveira ${ }^{1}$, Paulo Borges Rodrigues ${ }^{1^{*}}$ iD
}

\footnotetext{
${ }^{1}$ Universidade Federal de Lavras, Departamento de Zootecnia, Lavras, MG, Brasil.

${ }^{2}$ Universidade José do Rosário Vellano, Faculdade de Agronomia, Alfenas, MG, Brasil.
}

\begin{abstract}
The objective of the current study was to evaluate the effects of three calcium:available phosphorus (Ca:aP) ratios and different supplementation with phytases from different origins on performance and ash, Ca, and $\mathrm{P}$ contents in the tibia of broilers. A total of 900 male broilers (22 to 35 days old) were fed ten dietary treatments in a completely randomized design. A $3 \times 3+1$ factorial scheme was used, corresponding to three Ca:aP ratios $(4.5: 1.0,6.0: 1.0$, and $7.5: 1.0)$ and three different supplementations with phytases from different origins (isolated or combined supplementation with bacterial and fungal phytase), plus a control diet. Regardless of the dietary Ca:aP ratio, the isolated use of bacterial phytase provided better feed conversion than the fungal phytase but did not differ from combined supplementation with bacterial and fungal phytase. However, regardless of the supplemented phytase, the 7.5:1.0 Ca:aP ratio decreased the feed conversion. Best results for bone $\mathrm{P}$ deposition were observed using diets containing the 4.5:1.0 Ca:aP and fungal phytase or the 4.5:1 and 6.0:1 Ca:aP ratios using the bacterial phytase. In general, when the parameters of feed conversion, bone ash, and $\mathrm{P}$ content in tibia are considered together, diets containing a 4.5:1.0 or 6.0:1.0 Ca:aP ratio and 1,500 $\mathrm{FTU} \mathrm{kg}^{-1}$ bacterial phytase, or a 4.5:1.0 Ca:aP ratio using fungal phytase and only $1.0 \mathrm{~g} \mathrm{~kg}^{-1}$ available phosphorus provide better results.
\end{abstract}

Key Words: enzyme, nutrition, phytate, phytic acid

\section{Introduction}

Approximately two-thirds of the phosphorus in vegetal foods is excreted without digestion (Lalpanmawia et al., 2014) and phytic acid has the ability to bind with divalent cations, including calcium (Selle et al., 2009). Nutritionally, phytate-mineral complexes are very important because the bound nutrients cannot be absorbed in the intestine (Lei and Porres, 2003). Moreover, the insoluble Ca-phytate complexes are resistant to enzymatic hydrolysis by phytases (Taylor, 1965).

Phytases (myo-inositol hexaphosphate phosphohydrolases) hydrolyse phosphoester bonds of phytates, making the hydrolysed P potentially available to the birds (Han et al., 2009). Depending on the microorganism used as gene donor

Received: November 14, 2017

Accepted: June 9, 2018

*Corresponding author: pborges@dzo.ufla.br

Copyright (c) 2018 Sociedade Brasileira de Zootecnia. This is an Open Access article distributed under the terms of the Creative Commons Attribution License (http://creativecommons.org/licenses/by/4.0/), which permits unrestricted use, distribution, and reproduction in any medium, provided the original work is properly cited. for the industrial production of phytases, these enzymes can be classified as bacterial or fungal (Selle and Ravindran, 2007). Therefore, microbial phytases can have different physicochemical and catalytic properties (Mullaney and Ullah, 2003), which can influence the performance and bone mineralization of broilers in different ways.

Dietary Ca plays the most important role in minimizing phytase effectiveness (Angel et al., 2002). High levels of $\mathrm{Ca}$ and $\mathrm{Ca}$ available phosporus (Ca:aP) ratios in the diet decrease the exogenous phytase efficacy (Lei et al., 1994), and a deficiency of $\mathrm{Ca}$ and $\mathrm{P}$ could compromise bone structure and broiler performance (Selle et al., 2009). According to Bedford and Rousseau (2017), when diets meet, but do not exceed the $\mathrm{P}$ requirements of the bird, a marginal $\mathrm{Ca}$ excess can interfere with $\mathrm{P}$ digestibility, and this problem is exacerbated when phytases are used to provide some of the required $\mathrm{P}$, because $\mathrm{Ca}$ decreases the efficiency of phytate hydrolysis in a dose-dependent manner. However, few studies have evaluated the action of phytase and the $\mathrm{Ca}: \mathrm{aP}$ ratio on bone mineralization and broiler performance in the growing phase. Furthermore, according to Rostagno et al. (2017), during the growing phase (22 to 35 days), broilers have the highest feed intake in relation to the other 
phases, and this has a great impact on bone mineralization and animal development.

Initially, phytase was included in broiler diets at $500 \mathrm{FTU} \mathrm{kg}{ }^{-1}$ concentration. However, currently, higher inclusion rates are being considered (Cowieson et al., 2011). The benefits of supplementing a high phytase dose has been shown in broilers through inositol provision and phytate destruction (Walk at al., 2014; Li et al., 2017). There are still few studies with fungal phytase individually or in combination with bacterial phytase for broilers in the growing phase. This assay was carried out to evaluate the effects of $\mathrm{Ca}$ :aP ratios and phytases from different origins and isolated or combined supplementation on performance and ash, $\mathrm{Ca}$, and $\mathrm{P}$ contents in tibia of broilers.

\section{Material and Methods}

The experimental procedure was approved by the institutional committee on animal use (case no. 004/11). The trials were conducted in Lavras, MG, Brazil (21 $1^{\circ} 13^{\prime} 48^{\prime \prime} \mathrm{S}$, $44^{\circ} 58^{\prime} 23^{\prime \prime} \mathrm{W}$, and $918 \mathrm{~m}$ altitude). Nine hundred male Cobb$500^{\circledR}$ broilers of 22 to 35 days old were used. One-day-old chicks were purchased from a commercial hatchery and reared, in a single lot, in a conventional broiler shed for 21 days. During this period, broilers had access to feed and water ad libitum. The diet was based on corn-soybean meal formulated to meet the nutritional requirements of birds at 1-7 days and 8-21 days of age, according to Rostagno et al. (2011).

At 22 days of age, birds were weighed individually, separated by weight ranges $(936.4 \pm 9.9 \mathrm{~g})$, divided into groups of 15 birds, and placed randomly in 60 floor pens $(2.0 \times 1.5 \mathrm{~m})$ with wood shavings. The experimental diets and water were provided ad libitum during the experimental phase. Fluorescent bulbs and natural day light provided $24 \mathrm{~h}$ of light per day during the experimental assay. The average maximum and minimum temperatures in the shed during the experiment were 34 and $19.9^{\circ} \mathrm{C}$, respectively. The average maximum and minimum relative humidity were 97 and $42 \%$, respectively.

The 900 birds were distributed into 10 treatments with six replications each, for a total of 60 experimental units of 15 birds each. A $3 \times 3+1$ factorial scheme was used, corresponding to three $\mathrm{Ca}$ :aP ratios $(4.5: 1.0,6.0: 1.0$, and 7.5:1.0) and three supplementations of phytases from different origins (isolated or combined supplementation with bacterial and fungal phytase), plus a positive control diet formulated with 7.5:3.4 Ca:aP ratio and without phytase supplementation. In the diets containing only one phytase, the enzyme was included at $1,500 \mathrm{FTU} \mathrm{kg}^{-1}$ concentration.
In the diets containing the two evaluated phytases, each enzyme was supplemented at $750 \mathrm{FTU} \mathrm{kg}^{-1}$ concentration. The phytase inclusion level used in the present study, as well as the broiler age, were defined according to previous assays (Naves et al., 2015)

The bacterial phytase (RONOZYME HiPhos ${ }^{\circledR}$ ) corresponds to an enzyme expressed by Aspergillus oryzae genetically modified with Citrobacter braakii genes (phytase with 9,875 FTU kg-1 analysed activity). The fungal phytase (NATUPHOS ${ }^{\circledR}$ ) was produced by Aspergillus niger genetically modified with Aspergillus ficuum gene (phytase with 9,917 FTU kg-1 analysed activity). The Ca:aP ratios were adjusted according to the amount of limestone in the diets. Experimental diets (Table 1) were based on corn and soybean meal and fed in crumbled form. The positive control diet, without phytase, was formulated according to Rostagno et al. (2011). The experimental diets containing phytase had $1.06 \mathrm{~g} \mathrm{~kg}^{-1}$ aP and variable $\mathrm{Ca}$ levels, according to treatments, and it was considered that the phytase would make the phytic $\mathrm{P}$ available to meet the requirements of aP recognised by Rostagno et al. (2011), that was $0.342 \%$ in the analysed phase.

The broilers, allocated by pen, were weighed on the first and last experimental days (days 22 and 35, respectively) to determine the weight gain (WG). Feed intake (FI) was measured from 22 to 35 days old and was used to calculate the feed conversion ratio (FCR). Mortality was recorded daily, in the morning and afternoon, and when mortality occurred in a pen, the feed was weighted to correct FI and FC. At 35 days of age, two birds from each replication, representing the average weight of each pen, were sacrificed by cervical dislocation to collect the left tibia.

The left tibial bones were dissected, thoroughly cleaned manually by removing adhering muscles, together with connective tissues, and dried in a hot-air oven at $105{ }^{\circ} \mathrm{C}$ for $12 \mathrm{~h}$. These tibiae were then degreased in a fat extractor with ethyl ether for approximately $12 \mathrm{~h}$, air dried, and then dried in a hot-air oven $\left(105^{\circ} \mathrm{C}\right)$ to constant weight. The tibiae were weighed and placed in a muffled furnace at $600{ }^{\circ} \mathrm{C}$ for $6 \mathrm{~h}$ to determine the ash content. Produced ashes were used to determine the $\mathrm{Ca}$ and $\mathrm{P}$ content using, respectively, methods 935.13 and 965.17 of the AOAC (2005).

The experimental data were subjected to one-way analysis of variance (ANOVA) using the $\mathrm{R}$ free software (R Development Core Team, 2012). The average of the factorial treatments was compared with the positive control diet by ANOVA and, when significant, the treatments of the factorial were compared to the control diet using the Dunnet test at 5\% probability (Dunnet, 1955). The supplemented 
Table 1 - Ingredients and nutrient composition of the diets $\left(\mathrm{g} \mathrm{kg}^{-1}\right.$ as fed) given to broilers from 22 to 35 days of age

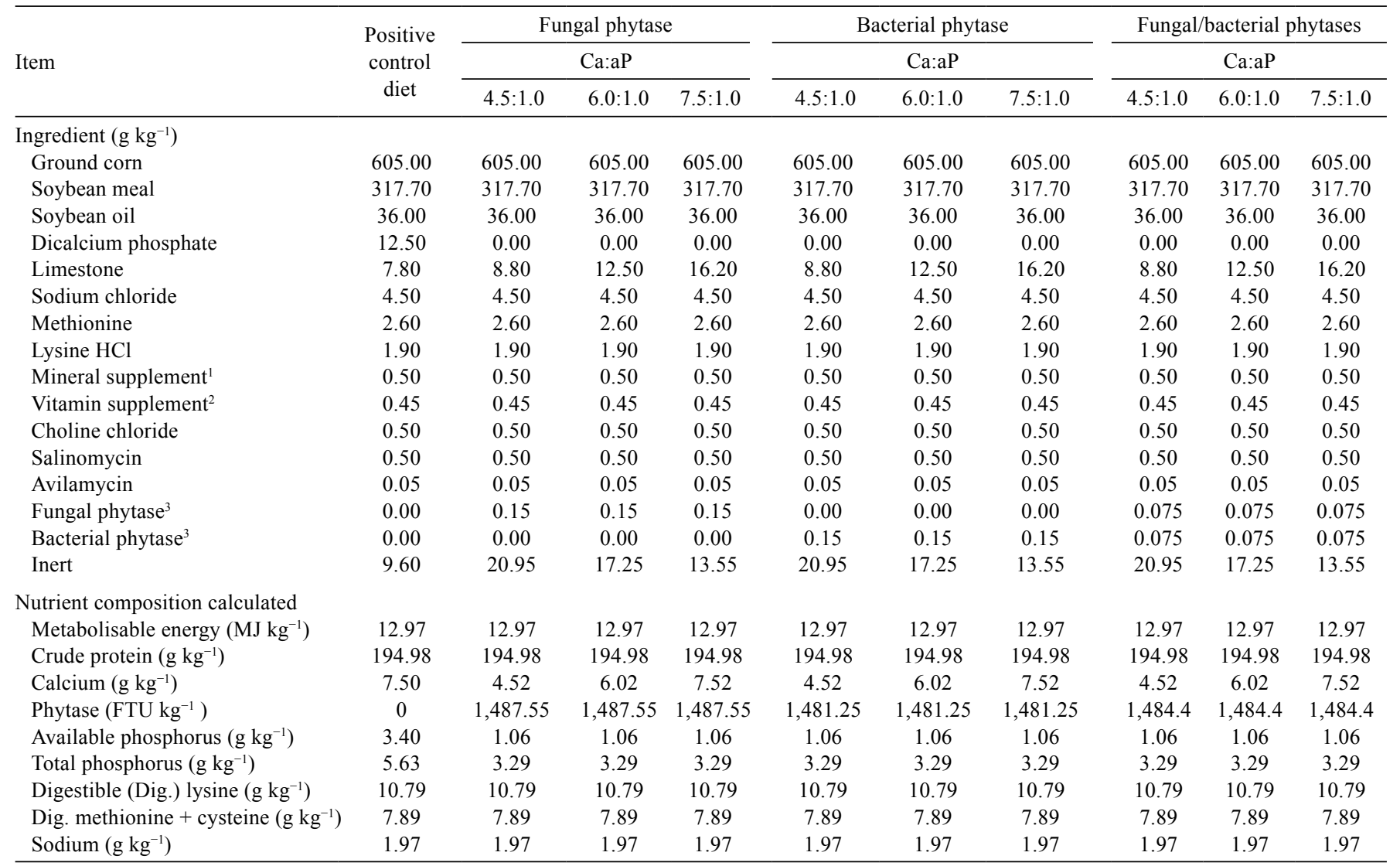

Ca:aP - calcium:available phosphorus ratio.

${ }^{1}$ Supplied per kg feed ${ }^{-1}$ : zinc, $55 \mathrm{mg}$; selenium, $0.18 \mathrm{mg}$; iodine, $0.70 \mathrm{mg}$; copper, $10 \mathrm{mg}$; manganese, $78 \mathrm{mg}$; iron, $48 \mathrm{mg}$.

${ }^{2}$ Supplied per kg feed ${ }^{-1}$ : retinol, $6 \mathrm{MIU}$; cholecalciferol, $1.5 \mathrm{MIU}$; tocopherol, $12.15 \mathrm{MIU}$; menadione $1.44 \mathrm{MIU}$; thiamine, $0.8 \mathrm{mg}$; riboflavin, $3.6 \mathrm{mg}$; pyridoxine, $1.8 \mathrm{mg}$; niacin,

$11.1 \mathrm{mg}$; pantothenate, $8.70 \mathrm{mg}$; folate, $0.48 \mathrm{mg}$; biotin, $0.018 \mathrm{mg}$; butylhydroxytoluene, $1.5 \mathrm{mg}$; cobalamin, $8.10 \mu \mathrm{g}$.

${ }^{3}$ Analysed activity of $9,917 \mathrm{FTU} \mathrm{kg}^{-1}$ for fungal phytase and $9,875 \mathrm{FTU} \mathrm{kg}^{-1}$ for bacterial phytase.

phytase and different $\mathrm{Ca}: \mathrm{aP}$ ratios were compared using the Student-Newman-Keuls test at $5 \%$ of probability (Newman, 1939).

\section{Results}

The phytase activity analysed was at $9,875 \mathrm{FTU}^{-1}$ for 6-phytase and 9,917 FTU kg-1 for 3-phytase.

There were no interactions $(\mathrm{P}>0.3)$ between the supplemented phytase and the Ca:aP ratio in the diet, and there was no isolated effect of these factors on FI $(\mathrm{P}>0.4)$ or WG $(\mathrm{P}>0.6)$ (Table 2). Moreover, there were no significant differences between the means of the experimental diets of the factorial and the control diet $(\mathrm{P}>0.5$ and $\mathrm{P}>0.9$ for feed intake and weight gain, respectively).

There was no interaction $(\mathrm{P}>0.1)$ between phytase and Ca:aP ratio for the FCR (Table 2), although there was isolated effect of the type of supplemented phytase $(\mathrm{P}=0.026)$ and the $\mathrm{Ca}$ :aP ratio $(\mathrm{P}=0.022)$. The best FCR was observed for the 7.5:1.0 Ca:aP ratio and a worse FCR was noted when fungal phytase was supplemented in an isolated manner.
However, the treatment means of the factorial phytase vs. $\mathrm{Ca}: \mathrm{aP}$ ratio were not significantly different $(\mathrm{P}>0.2)$ from the positive control diet. Regardless of the dietary Ca:aP ratio, the isolated supplementation of bacterial phytase, or a combination of fungal and bacterial phytase $\left(750 \mathrm{FTU} \mathrm{kg}^{-1}\right.$ of each) resulted in the best FCR, and the 4.5:1.0 or 6.0:1.0 $\mathrm{Ca}: \mathrm{aP}$ ratio, respectively, presented the worst FCR.

There was no interaction $(\mathrm{P}>0.15)$ between the supplemented phytase and dietary Ca:aP ratio or an isolated influence of the Ca:aP ratio on the tibia ash $(\mathrm{P}>0.75)$ or calcium concentration $(\mathrm{P}>0.4)$ in the tibia (Table 3$)$. However, there was a tendency $(\mathrm{P}=0.05)$ to lower tibia ash when the diet was supplemented with fungal phytase alone. Moreover, compared with the control diet, when fungal phytase was supplemented in diets with $\mathrm{Ca}: \mathrm{aP}$ ratios of $6.0: 1.0$ or $7.5: 1.0$, the tibia ash decreased $(\mathrm{P}=0.010)$.

The $\mathrm{Ca}$ concentrations in the tibia were not influenced by the supplemented phytase $(\mathrm{P}>0.15)$ or by the dietary Ca:aP ratio $(\mathrm{P}>0.4)$. Therefore, the average $\mathrm{Ca}$ concentration in the tibia of birds fed diets with phytase was similar to those fed the control diet $(\mathrm{P}>0.3)$. 
Table 2 - Performance of broilers (22 to 35 days old) fed diets with different calcium:available phosphorus ratio (Ca:aP) and supplemented with fungal and/or bacterial phytase

\begin{tabular}{|c|c|c|c|c|c|c|c|c|c|c|c|c|}
\hline & \multicolumn{4}{|c|}{ Feed intake $\left(\mathrm{g} \mathrm{bird}^{-1}\right)$} & \multicolumn{4}{|c|}{ Weight gain $\left(\mathrm{g} \mathrm{bird}^{-1}\right)$} & \multicolumn{4}{|c|}{ Feed conversion $\left(\mathrm{g} \mathrm{g}^{-1}\right)$} \\
\hline & \multicolumn{4}{|c|}{ Ca:aP } & \multicolumn{4}{|c|}{$\mathrm{Ca}: \mathrm{aP}$} & \multicolumn{4}{|c|}{$\mathrm{Ca}: \mathrm{aP}$} \\
\hline & $4.5: 1.0$ & $6.0: 1.0$ & $7.5: 1.0$ & Average & $4.5: 1.0$ & $6.0: 1.0$ & $7.5: 1.0$ & Average & $4.5: 1.0$ & $6.0: 1.0$ & $7.5: 1.0$ & Average \\
\hline Fungal phytase $\left(1500 \mathrm{FTU} \mathrm{kg}^{-1}\right)$ & 2197 & 2197 & 2179 & 2191 & 1271 & 1273 & 1307 & 1284 & 1.73 & 1.73 & 1.67 & $1.71 \mathrm{~A}$ \\
\hline Bacterial phytase (1500 FTU kg-1) & 2212 & 2183 & 2254 & 2216 & 1310 & 1307 & 1356 & 1324 & 1.69 & 1.67 & 1.66 & $1.67 \mathrm{~B}$ \\
\hline Fungal + bacterial phytase $\left(750 \mathrm{FTU} \mathrm{kg}^{-1}\right.$ each $)$ & 2265 & 2228 & 2184 & 2226 & 1358 & 1306 & 1304 & 1323 & 1.67 & 1.71 & 1.68 & $1.68 \mathrm{AB}$ \\
\hline Average & 2224 & 2203 & 2206 & & 1313 & 1295 & 1322 & & $1.70 \mathrm{a}$ & $1.70 \mathrm{a}$ & $1.67 \mathrm{~b}$ & \\
\hline Positive control diet ${ }^{1}$ & & & & 2190 & & & & 1313 & & & & 1.67 \\
\hline \multirow[t]{2}{*}{ SEM } & \multicolumn{4}{|c|}{33.193} & \multicolumn{4}{|c|}{23.916} & \multicolumn{4}{|c|}{0.0152} \\
\hline & \multicolumn{12}{|c|}{ Significance $(\mathrm{P}=)$} \\
\hline Phytase & \multicolumn{4}{|c|}{0.419} & \multicolumn{4}{|c|}{0.071} & \multicolumn{4}{|c|}{0.026} \\
\hline $\mathrm{Ca}: \mathrm{aP}$ & \multicolumn{4}{|c|}{0.684} & \multicolumn{4}{|c|}{0.384} & \multicolumn{4}{|c|}{0.022} \\
\hline Phytase $\times$ Ca:aP & \multicolumn{4}{|c|}{0.333} & \multicolumn{4}{|c|}{0.268} & \multicolumn{4}{|c|}{0.112} \\
\hline Additional treatment (positive control) & \multirow{2}{*}{\multicolumn{4}{|c|}{0.546}} & \multicolumn{4}{|c|}{0.921} & \multicolumn{4}{|c|}{0.233} \\
\hline Variation coefficient $(\%)$ & \multicolumn{3}{|c|}{3.68} & & \multicolumn{4}{|c|}{4.47} & \multicolumn{4}{|c|}{2.21} \\
\hline
\end{tabular}

SEM - standard error of the mean.

${ }^{1}$ Diet containing $7.5 \mathrm{~g}$ of calcium and $3.4 \mathrm{~g}$ of available phosphorus $\mathrm{kg}^{-1}$ of feed without supplemental phytase.

Means within rows $(\mathrm{a}, \mathrm{b})$ and columns $(\mathrm{A}, \mathrm{B})$ with different letters are significantly different at the $5 \%$ level of probability.

Table 3 - Bone ash, calcium, and phosphorus percentage in the tibia of broilers fed diets with different calcium:available phosphorus ratio (Ca:aP) supplemented with fungal and/or bacterial phytase from 22 to 35 days old

\begin{tabular}{|c|c|c|c|c|c|c|c|c|c|c|c|c|}
\hline & \multicolumn{4}{|c|}{ Ash $(\%)$} & \multicolumn{4}{|c|}{ Calcium (\%) } & \multicolumn{4}{|c|}{ Phosphorus (\%) } \\
\hline & \multicolumn{4}{|c|}{$\mathrm{Ca} a \mathrm{aP}$} & \multicolumn{4}{|c|}{$\mathrm{Ca}: \mathrm{aP}$} & \multicolumn{4}{|c|}{$\mathrm{Ca}: \mathrm{aP}$} \\
\hline & $4.5: 1.0$ & $6.0: 1.0$ & 7.5:1.0 & Average & $4.5: 1.0$ & $6.0: 1.0$ & $7.5: 1.0$ & Average & $4.5: 1.0$ & $6.0: 1.0$ & $7.5: 1.0$ & Average \\
\hline Bacterial phytase (1500 FTU kg $\left.{ }^{-1}\right)$ & 50.8 & 51.4 & 51.1 & 51.1 & 36.8 & 37.3 & 37.3 & 37.1 & $17.4 \mathrm{ab}$ & $18.2 \mathrm{Aa}$ & $16.4 \mathrm{~b}$ & 17.3 \\
\hline Fungal + bacterial phytase $\left(750 \mathrm{FTU} \mathrm{kg}^{-1}\right.$ each $)$ & 50.9 & 50.9 & 51.1 & 51.0 & 36.5 & 35.8 & 37.5 & 36.6 & 17.1 & 16.1B & 17.2 & 16.8 \\
\hline Average & 50.9 & 50.7 & 50.8 & & 36.5 & 36.3 & 37.2 & & 17.2 & 16.7 & 16.54 & \\
\hline \multirow[t]{2}{*}{ SEM } & \multicolumn{4}{|c|}{0.3837} & \multicolumn{4}{|c|}{0.7489} & \multicolumn{4}{|c|}{0.4172} \\
\hline & \multicolumn{12}{|c|}{ Significance $(\mathrm{P}=)$} \\
\hline Phytase & \multicolumn{4}{|c|}{0.050} & \multicolumn{4}{|c|}{0.173} & \multicolumn{4}{|c|}{0.022} \\
\hline $\mathrm{Ca}: \mathrm{aP}$ & \multicolumn{4}{|c|}{0.762} & \multicolumn{4}{|c|}{0.443} & \multicolumn{4}{|c|}{0.123} \\
\hline Phytase $\times$ Ca:aP & \multicolumn{4}{|c|}{0.182} & \multicolumn{4}{|c|}{0.476} & \multicolumn{4}{|c|}{0.007} \\
\hline
\end{tabular}

SEM - standard error of the mean.

${ }^{1}$ Diet containing $7.5 \mathrm{~g}$ of calcium and $3.4 \mathrm{~g}$ of available phosphorus $\mathrm{kg}^{-1}$ of feed without supplemental phytase.

* Differs from the positive control diet, according to Dunnet test at $5 \%$ probability.

Means within rows $(a, b)$ and columns $(A, B)$ with different letters are significantly different at the $5 \%$ level of probability.

There were interactions of the supplemented phytase with the Ca:aP ratio on the percentage of $\mathrm{P}$ in the tibia $(P=0.007)$. It was observed that the fungal phytase supplemented in a diet with the 4.5:1.0 Ca:aP ratio resulted in the highest tibia $\mathrm{P}$ concentration. The bacterial phytase supplemented in dietary 7.5:1.0 Ca:aP ratio reduced $\mathrm{P}$ in the tibia. In contrast, when the diet was formulated with the 6.0:1.0 Ca:aP ratio and supplemented with a bacterial phytase, a higher P percentage was observed in the tibia (Table 3). Regardless of these results, $P$ concentration in the tibia of broilers supplemented with phytase and different $\mathrm{Ca}$ :aP ratios was similar $(\mathrm{P}>0.45)$ to that of broilers that received the control diet.

\section{Discussion}

According to Rostagno et al. (2011), the aP and Ca requirements for 22-35 day-old broilers are, respectively, 0.342 and $0.732 \%$. In the present study, the supplementation of 1,500 FTU phytase $\mathrm{kg}^{-1}$ in diets with 4.5:1.0 to 7.5:1.0 $\mathrm{Ca}$ :aP ratios did not influence FI and WG, suggesting that the enzymes supplemented in isolated or combined manners assisted phytate hydrolysis and, as a consequence, released $\mathrm{P}$ and other nutrients, such as $\mathrm{Ca}$, or the phytase supplementation may have improved $\mathrm{Ca}$ utilization due to decreased phytate-Ca complex formation in the poultry gastrointestinal tract. 
Minerals play an important role in broiler nutrition, in terms that their deficiency or excess in the diet prevents poultry from expressing their full potential during the growth stage (Muniz et al., 2007). When compared to the control diet, there was also no effect of the treatments on the performance of birds. Recently, Jiang et al. (2016) concluded that the level of aP for broilers fed a basal diet with maize and soybean meal in the period from 22 to 42 days of age should be $0.31 \%$. According to Parmer et al. (1987), P deficiency in poultry decreases both FI and circulating levels of growth hormones. Therefore, the lack of influence of the experimental treatments on FI and WG indicated that during the analysed growth period, there was no deficiency of $\mathrm{P}$ or other nutrients that was sufficient to impair performance, even in diets considered deficient in Ca and P, and, according to Gautier et al. (2018), the phytase has the ability to release $\mathrm{P}$ and other nutrients as part of the phytate complex.

The results found in this study corroborated the findings of Naves et al. (2016), who analysed the efficiency of six different microbial phytases in 35-42 day-old broilers fed diets containing $1500 \mathrm{FTU} \mathrm{kg}^{-1}$ and formulated with three different $\mathrm{Ca}: \mathrm{aP}$ ratios $(3.5: 1.0,5.0: 1.0$, and $6.5: 1.0)$ and observed no interactions or isolated effects of the different Ca:aP ratios in the diet on FI and WG.

On the other hand, Gautier et al. (2018), analysing three different mineral matrices (control diet with $1.0 \% \mathrm{Ca}$ and $0.5 \%$ aP; mineral matrix 1 with $0.84 \% \mathrm{Ca}$ and $0.35 \%$ aP; and mineral matrix 2 with $0.77 \% \mathrm{Ca}$ and $0.29 \% \mathrm{aP}$ ) and 0 or $1500 \mathrm{FTU} \mathrm{kg}^{-1}$ phytase supplementation in broiler diets, observed that phytase increased WG, regardless of the mineral matrix applied. They also observed that FI was influenced by the mineral matrix, in which birds fed matrix 1 exhibited increased FI, while birds fed matrix 2 concomitantly exhibited a decrease in FI, relative to the control. However, they did not find significant effects of either mineral matrix or phytase addition on feed efficiency. Kim et al. (2017) observed that increasing Ca concentration in diets containing phytase decreased WG and FI. According to Bedford and Rousseau (2017), calcium has recently been shown to reduce the efficacy of hydrolysis of the lower phytate esters (IP4, IP3, and IP2) to a greater degree than the extent to which it decreases IP6 hydrolysis. Thus, Ca concentrations in the diet should be monitored frequently if the maximum value of a phytase is to be realised.

The statistical difference found for the FCR shows that the use of bacterial phytase, regardless of the Ca:aP ratio, was more efficient than isolated supplementation with the fungal phytase in making nutrients available as phytate in the feed. Phytates influence the endogenous phytase secretion and activity (Liu et al. 2009) and reduce the digestibility of amino acids and minerals (Cowieson et al., 2006a,b). Moreover, according to Wodzinski and Ullah (1996), fungal phytase cannot hydrolyse inositol monophosphate, while bacterial phytase completely hydrolyses phytic acid. The increase in the dietary Ca:aP ratio decreased the FCR, and the 7.5:1.0 Ca:aP ratio provided the best FCR, indicating that a feed containing $7.5 \mathrm{~g} \mathrm{Ca} \mathrm{kg}^{-1}$ provided the $\mathrm{Ca}$ requirements. However, as $\mathrm{Ca}$ levels decreased to amounts lower than $7.5 \mathrm{~g} \mathrm{~kg}^{-1}$, this nutrient seemed to become deficient in the diet, negatively influencing FCR for broilers.

The addition of phytase to broiler diets increased tibia ash at a ratio proportional to that of $\mathrm{P}$ release, inferring that the level of tibia ash was a very sensitive indicator of the P status (Lalpanmawia et al., 2014). This statement supported the results observed in the present study, as the supplementation of fungal phytase at the 6.0:1.0 and 7.5:1 Ca:aP ratios provided concomitantly lower bone ash contents, compared with the control diet, and lower $\mathrm{P}$ contents, compared with when the fungal phytase was supplemented at the 4.5:1 Ca:aP ratio. This may have occurred because the diets that have the $6.0: 1$ and 7.5:1 $\mathrm{Ca}: \mathrm{aP}$ ratios probably presented an excess of $\mathrm{Ca}$, which minimised the effectiveness of fungal phytase in releasing $\mathrm{P}$. Qian et al. (1997) suggested that the extra Ca may directly suppress phytase activity by competing for the active sites of enzymes.

Ravindran et al. (2008) reported that phytases were more efficient in low $\mathrm{Ca}$ diets and low $\mathrm{Ca}: \mathrm{P}$ ratios. Amerah et al. (2014), investigated the effect of four Ca:aP ratios $(1.43,2.14,2.86$, and 3.57$)$ and two phytase levels $(0$ and 1,000 FTU $\mathrm{kg}^{-1}$ ) in broiler diets and observed that increasing the $\mathrm{Ca}: \mathrm{aP}$ ratio reduced phytate degradation quadratically and P digestibility linearly. Li et al. (2017) reported the detrimental impact of Ca on IP6 disappearance in the ileum, in which 11\% reduction in IP6 disappearance was observed when $\mathrm{Ca}$ increased from 0.7 to $1.0 \%$. These observations may, in part, justify the results obtained in the current study.

Tamin and Angel (2003) mentioned that this was probably due to excess $\mathrm{Ca}$ binding with the phytate or phytic acid molecule, forming compounds that were not easily degraded by phytases. Nelson and Kirby (1987) showed that increasing $\mathrm{Ca}$ levels in broiler diets from 1.2 to $5.2 \mathrm{~g} \mathrm{~kg}^{-1}$ decreased phytate hydrolysis from 55 to $6 \%$, respectively. In addition, according to Rao and Rao (1983), reducing Ca in the diet from 10.0 to $5.0 \mathrm{~g} \mathrm{~kg}^{-1}$ feed increased phytate hydrolysis in broilers by $15 \%$. Gautier et al. (2017) conducted an experiment to determine the 
influence of dietary $\mathrm{Ca}$ concentrations and observed that increasing the dietary Ca concentration ( 0.4 to $1.6 \%$ of total $\mathrm{Ca}$ ), while maintaining $0.3 \% \mathrm{aP}$, elicited linear reductions in overall growth performance and tibia ash.

Recently, Kim et al. (2017) evaluated dietary $\mathrm{Ca}$ concentrations from 6.0 to $10.0 \mathrm{~g} \mathrm{~kg}^{-1}$ in low aP diets containing phytase and observed that $\mathrm{Ca}$ and $\mathrm{P}$ concentrations in the tibia decreased if dietary $\mathrm{Ca}$ concentrations were less than $5.0 \mathrm{~g} \mathrm{~kg}^{-1}$ in diets supplemented with 1,000 phytase units $\mathrm{kg}^{-1}$. These results were contrary to those of the present study, in which $\mathrm{P}$ concentration in the tibia increased when diets were formulated with lower Ca levels in diets formulated with 1,500 FTU $\mathrm{kg}^{-1}$, but with $1.0 \mathrm{~g} \mathrm{aP} \mathrm{kg}^{-1}$.

It has been suggested that a diet with a molar ratio of Ca:phytic acid greater than 6:1 leads to formation of insoluble Ca-phytate complexes that are inaccessible to diet or intestinal phytases (Wise et al., 1983).

According to Bedford et al. (2016), an increase in dietary $\mathrm{Ca}$ may hamper the ability of phytase to act on dietary phytate and release the same amount of $\mathrm{P}$ that would be released from a diet with lower Ca levels. In addition, the referred authors mentioned that a higher $\mathrm{P}$ level in the diet resulted in less phytase activity on the substrate.

According to the results of $\mathrm{P}$ concentration in the tibia of birds, it may be inferred that the bacterial phytase was the most efficient in hydrolysing phytates. However, its use with the highest $\mathrm{Ca}: \mathrm{aP}$ in the diet (7.5:1.0) led to the lowest $\mathrm{P}$ deposition in the tibia, reinforcing the theory that higher amounts of $\mathrm{Ca}$ in the feed can negatively impact the phytase catalytic efficacy. However, this effect was not observed on bone ash or $\mathrm{Ca}$ levels in the tibia using high $\mathrm{Ca}$, and the results of these parameters were similar to the control diet, but the best FCR was observed at 7.5:1.0 Ca:aP ratio.

Phytases have been suggested to vary in their $\mathrm{pH}$ optima with hydrolysing phytate efficiency and speed depending on their source (Tran et al., 2011). Selle et al. (2009) hypothesised that Ca-phytate complexes were mainly formed in the small intestine, and exogenous phytases of bacterial origin would be more active in more proximal segments of the gut where the $\mathrm{pH}$ was closer to the optimum $\mathrm{pH}$ of the phytase.

In study with broilers fed diets supplemented with different concentrations of bacterial phytase, $\mathrm{Ca}$, and phytate $\mathrm{P}$, Li et al. (2017) observed a substantial reduction in IP6 in both the crop proventriculus and gizzard, as a result of 500 and 1,000 FTU bacterial phytase $/ \mathrm{kg}$ inclusion, regardless of diet $\mathrm{Ca}$ concentrations. Zeller et al. (2015) reported that the main IP in the gizzard from IP6 hydrolysis was IP4 for bacterial phytases (E. coli), whereas there was no apparent lower IP esters accumulation in the gizzard when fungal phytase (A. niger) was provided to broilers. In agreement with the findings of Zeller et al. (2015), the bacterial phytase was more effective to hydrolyse $\mathrm{P}$ than fungal phytase in the current study.

Amerah et al. (2014) suggested in their studies that bacterial phytases, which hydrolyse phytate at low $\mathrm{pH}$ in the proximal intestinal tract, may be less prone to inhibition by higher dietary $\mathrm{Ca}$ levels. This may explain why the tibia ash contents of the broilers that received supplementation with bacterial phytase at the 6.0:1.0 and 7.5:1 Ca:aP ratios did not differ from the those of the control group.

The fact that broilers fed diets supplemented with phytase in the different evaluated manners, except for diet containing fungal phytase and the 6.0:1.0 and 7.5:1.0 Ca:aP ratios, obtained bone ash level similar to that of the birds receiving the control diet, is probably related to the phytase efficacy, particularly increasing development, previously bound to the phytate molecule. It is worth noting that, in the present study, the birds were evaluated at 35 days of age, and the bioavailability not only of $\mathrm{P}$ but also of other minerals involved in bone at this evaluated stage (22 to 35 days old) may still be developing; therefore, a larger mineral supply may be needed.

For the 6.0:1.0 and 7.5:1.0 Ca:aP ratios, the fungal phytase was the least effective in hydrolysing phytates and making P more bioavailable, which negatively and directly impacted both the $\mathrm{P}$ content and bone mineralization in broilers. However, birds that received supplementation with fungal phytase and 6.0:1.0 and 7.5:1.0 Ca:aP ratios performed similarly to birds that received the recommended Ca:aP levels during this study.

This led to the inference that $P$ levels lower than those recommended for broiler diets first impacted $\mathrm{P}$ levels in the tibia and, as a consequence, bone mineralization, but not broiler performance. Probably this effect was not observed for $\mathrm{Ca}$ at the different levels evaluated due the fact that phytase hydrolised the phytate $\mathrm{P}$ and, thus prevented, $\mathrm{Ca}$ from being complexed.

Phosphorus is quantifiably more important for bone mineralization than for soft tissue growth, because $\mathrm{P}$ is a major component of the skeleton of birds. Broilers may become more vulnerable to mineral imbalances as $\mathrm{Ca}$ and non-phytate phosphorus concentrations are reduced, because bone mineralization requirements are met before growth requirements when $\mathrm{P}$ nutrition is the focus (Gautier et al., 2018).

Several authors have also reported that the $\mathrm{P}$ requirements to optimize performance were lower than that needed to maximise bone development (Libal et al., 1969; Koch et al. 1984; Gomes et al., 1993; Gautier et al., 2018). 
Mello et al. (2012) came to the same conclusion while determining the aP dietary requirements of broilers during the growing stage (22 to 33 days old) fed the same Ca:aP ratio. According to that study, lower levels of aP improved WG and FC, but failed to improve bone parameters in poultry. Waldroup (1999) suggested that, in relative terms, $\mathrm{P}$ requirements follow the sequence bone calcification $>$ body weight $>$ feed efficiency $>$ mortality.

Naves et al. (2014) analysed the use of phytase-equivalent amounts as a basis to decrease the aP in broiler diets from eight to 21 days of age. They concluded that decreasing the amount of dietary aP from 3.9 to $2.5 \mathrm{~g} \mathrm{~kg}^{-1}$ and, at the same time, supplementing with $1,500 \mathrm{FTU} \mathrm{kg}^{-1}$, maintained performance and bone ash levels similar to those of broilers fed diets containing $3.9 \mathrm{~g} \mathrm{~kg}^{-1}$ aP without phytase.

Phytase proved to be efficient in releasing $\mathrm{Ca}$. In addition, tibia $\mathrm{Ca}$ levels of birds subjected to different treatments performed in a very similar way (some diets had low $\mathrm{Ca}$ levels compared with recommendations in the literature) to birds receiving the control diet. Similarly, Augspurger and Baker (2004) studied broilers fed a corn-soybean-based diet deficient in $\mathrm{Ca}\left(4.8 \mathrm{~g} \mathrm{~kg}^{-1}\right)$ and supplemented with bacterial (E. coli) phytase (500 FTU kg ${ }^{-1}$ ) and, based on tibial ash analysis, concluded that phytase released, on average, $0.90 \mathrm{~g} \mathrm{Ca} \mathrm{kg}^{-1}$ feed. However, Yan et al. (2006) studied the addition of $1,000 \mathrm{FTU} \mathrm{kg}^{-1}$ phytase in corn and soybean meal-based diets, including three $\mathrm{Ca}$ and eight non-phytic P levels, and concluded that phytase released minimal amounts of $\mathrm{Ca}$ in broilers.

\section{Conclusions}

The use of phytases (1,500 FTU kg-1 feed) in growing broilers, 22-35 days old, can improve the diets containing 4.5:1.0 and 6.0:1.0 Ca:aP ratios with only $1.0 \mathrm{~g} \mathrm{~kg}^{-1} \mathrm{aP}$, as well as 4.5:1.0 for the fungal phytase, without negatively affecting bird performance or bone mineralization. However, when enzymes are combined (750 FTU fungal phytase +750 FTU bacterial phytase), the Ca:aP in the diet has no impact on the concentration of available phosphorus.

\section{Acknowledgments}

The authors acknowledge the financial support of the Conselho Nacional de Desenvolvimento Científico e Tecnológico (CNPq), Fundação de Amparo à Pesquisa do Estado de Minas Gerais (FAPEMIG), Coordenação de Aperfeiçoamento de Pessoal de Nível Superior (CAPES), and Instituto Nacional de Ciência e Tecnologia de Ciência Animal (INCT-CA).

\section{References}

Amerah,A. M.; Plumstead, P. W.; Barnard, L. P. and Kumar, A. 2014. Effect of calcium level and phytase addition on ileal phytate degradation and amino acid digestibility of broilers fed corn-based diets. Poultry Science 93:906-915. https://doi.org/10.3382/ps.2013-03465

Angel, R.; Tamim, N. M.; Applegate, T. J.; Dhandu, A. S. and Ellestad, L. E. 2002. Phytic acid chemistry: influence on phytin-phosphorus availability and phytase efficacy. Journal of Applied Poultry Research 11:471-480. https://doi.org/10.1093/japr/11.4.471

AOAC - Association of Official Analytical Chemists. 2005. Official methods of analysis. 18th ed. AOAC, Gaithersburg, Maryland, USA.

Augspurger, N. R. and Baker, D. H. 2004. Phytase improves dietary calcium utilization in chicks, and oyster shell, carbonate, citrate, and citrate-malate forms of calcium are equally bioavailable. Nutrition Research 24:293-301. https://doi.org/10.1016/j.nutres.2003.11.005

Bedford, M. R.; Walk, C. L. and Masey O’Neill, H. V. 2016. Assessing measurements in feed enzyme research: Phytase evaluations in broilers. Journal of Applied Poultry Research 25:305-314. https://doi.org/10.3382/japr/pfv073

Bedford, M. R. and Rousseau, X. 2017. Recent findings regarding calcium and phytase in poultry nutrition. Animal Production Science 57:2311-2316. https://doi.org/10.1071/AN17349

Cowieson, A. J.; Acamovic, T. and Bedford, M. R. 2006a. Phytic acid and phytase: implications for protein utilization by poultry. Poultry Science 85:878-885. https://doi.org/10.1093/ps/85.5.878

Cowieson, A. J.; Acamovic, T. and Bedford, M. R. $2006 \mathrm{~b}$. Supplementation of corn-soy-based diets with an Escherichia coli derived phytase: effects on broiler chick performance and the digestibility of amino acids and metabolizability of minerals and energy. Poultry Science 85:1389-1397. https://doi.org/10.1093/ ps/85.8.1389

Cowieson, A. J.; Wilcock, P. and Bedford, M. R. 2011. Super-dosing effects of phytase in poultry and other monogastrics. World's Poultry Science Journal 67:225-236. https://doi.org/10.1017/ S0043933911000250

Dunnet, C. W. 1955. A multiple comparison procedure for comparing several treatments with a control. Journal of the American Statistical Association 50:1096-1121.

Gautier, A. E.; Walk, C. L. and Dilger, R. N. 2017. Influence of dietary calcium concentrations and the calcium-to-non-phytate phosphorus ratio on growth performance, bone characteristics, and digestibility in broilers. Poultry Science 96:2795-2803. https://doi.org/10.3382/ps/pex096

Gautier, A. E.; Walk, C. L. and Dilger, R. N. 2018. Effects of a high level of phytase on broiler performance, bone ash, phosphorus utilization, and phytate dephosphorylation to inositol. Poultry Science 97:211-218. https://doi.org/10.3382/ps/pex291

Gomes, P. C.; Gomes, M. F. M.; Lima, G. J. M. M. and Bellaver, C. 1993. Phosphorus requirement and its availability in monoamonium and monocalcium phosphates for 21-day-old broilers. Revista da Sociedade Brasileira de Zootecnia 22:755-763.

Han, J. C.; Yang, X. D.; Qu, H. X.; Xu, M.; Zhang, T.; Li, W. L.; Yao, J. H.; Liu, Y. R.; Shi, B. J.; Zhou, Z. F. and Feng, X. Y. 2009. Evaluation of equivalency values of microbial phytase to inorganic phosphorus in 22- to 42-day-old broilers. Journal of Applied Poultry Research 18:707-715. https://doi.org/10.3382/japr.2009-00029

Jiang, Y.; Lu, L.; Li, S. F.; Wang, L.; Zhang, L. Y.; Liu, S. B. and Luo, X. G. 2016. An optimal dietary non-phytate phosphorus level of broilers fed a conventional corn-soybean meal diet from 4 to 6 weeks of age. Animal 10:1626-1634. https://doi.org/10.1017/S1751731116000501

Kim, J. H.; Jung, H.; Pitargue, F. M.; Han, G. P.; Choi1, H. S. and Kil1, D. Y. 2017. Effect of dietary calcium concentrations in low non-phytate phosphorus diets containing phytase on growth performance, bone mineralization, litter quality, and footpad dermatitis incidence in 
growing broiler chickens. Asian-Australasian Journal of Animal Sciences 30:979-983. https://doi.org/10.5713/ajas.17.0112

Koch, M. E.; Mahan, D. C. and Corley, J. R. 1984. An evaluation of various biological characteristics in assessing low phosphorus intake in weanling swine. Journal of Animal Science 59:1546-1556.

Lalpanmawia, H.; Elangovan, A. V.; Sridhar, M.; Shet, D.; Ajith, S. and Pal, D. T. 2014. Efficacy of phytase on growth performance, nutrient utilization and bone mineralization in broiler chicken. Animal Feed Science and Technology 192:81-89. https://doi.org/ 10.1016/j.anifeedsci.2014.03.004

Lei, X. G.; Ku, P. K.; Miller, E. R.; Yokoyama, M. T. and Ullrey, D. E. 1994. Calcium level affects the efficacy of supplemental microbial phytase in corn-soybean meal diets of weanling pigs. Journal of Animal Science 72:139-143. https://doi.org/10.2527/1994.721139x

Lei, X. G. and Porres, J. M. 2003. Phytase enzymology, applications, and biotechnology. Biotechnology Letters 25:1787-1794. https://doi.org/10.1023/A:1026224101580

Li, W.; Angel, R.; Kim, S.W.; Brady, K.; Yu, S. and Plumstead, P. W. 2017. Impacts of dietary calcium, phytate, and phytase on inositol hexakisphosphate degradation and inositol phosphate release in different segments of digestive tract of broilers. Poultry Science 96:3626-3637.

Libal, G. W.; Peo, E. R.; Andrews, R. P. and Vipperman, P. E. 1969. Levels of calcium and phosphorus for growing-finishing swine. Journal of Animal Science 28:331-335.

Liu, N.; Ru, Y. J.; Li, F. D.; Wang, J. P. and Lei, X. Q. 2009. Effect of dietary phytate and phytase on proteolytic digestion and growth regulation of broilers. Archives of Animal Nutrition 63:292-303. https://doi.org/10.1080/17450390903020422

Mello, H. H. C.; Gomes, P. C.; Rostagno, H. S.; Albino, L. F. T.; Rocha, T. C.; Almeida, R. L. and Calderano, A. A. 2012. Dietary requirements of available phosphorus in growing broiler chickens at a constant calcium:available phosphorus ratio. Revista Brasileira de Zootecnia 41:2323-2328. https://doi.org/10.1590/S1516-35982012001100004

Mullaney, E. J. and Ullah, A. H. J. 2003. The term phytase comprises several different classes of enzymes. Biochemical and Biophysical Research Communications 312:179-184. https://doi.org/10.1016/ j.bbrc.2003.09.176

Muniz, E. B.; Arruda, A. M. V.; Fassani, E. J.; Teixeira, A. S. and Pereira, E. S. 2007. Evaluation of calcium sources to the broiler chickens. Revista Caatinga 20:05-14.

Naves, L. P.; Rodrigues, P. B.; Bertechini, A. G.; Lima, E. M. C.; Teixeira, L. V.; Alvarenga, R. R.; Nardelli, N. B. S.; Oliveira, D. H. and Oliveira, M. H. 2014. Reduction of phosphorus in broiler diets based on equivalency values of phytase. Pesquisa Agropecuária Brasileira 49:71-77. https://doi.org/10.1590/S0100-204X2014000100010

Naves, L. P.; Rodrigues, P. B.; Teixeira, L. V.; Oliveira, E. C.; Saldanha, M. M.; Alvarenga, R. R.; Correa, A. D. and Lima, R. R. 2015. Efficiency of microbial phytase supplementation in diets formulated with different calcium:phosphorus ratios, supplied to broilers from 22 to 33 days old. Journal of Animal Physiology and Animal Nutrition 99:139-149. https://doi.org/10.1111/jpn.12186

Naves, L. P.; Rodrigues, P. B.; Meneghetti, C.; Bernardino, V. M. P.; Oliveira, D. H.; Saldanha, M. M.; Teixeira, L. V. and Santos, L. M. 2016. Efficiency of microbial phytases in diets formulated with different calcium:phosphorus ratios supplied to broilers from 35 to 42 days of age. The Journal of Applied Poultry Research 44:446-453. https://doi.org/10.1080/09712119.2015.1091324

Nelson, T. S. and Kirby, L. K. 1987. The calcium binding properties of natural phytate in chick diets. Nutrition Reports International 35:949-956.

Newman, D. 1939. The distribution of range in samples from a normal population expressed in terms of an independent estimate of standard deviation. Biometrika 31:20-30.

Parmer, T. G.; Carew, L. B.; Alster, F. A and Scanes, C. G. 1987. Thyroid function, growth hormone, and organ growth in broilers deficient in phosphorus. Poultry Science 66:1995-2004. https:// doi.org/10.3382/ps.0661995

Qian, H.; Kornegay, E. T. and Denbow, D. M. 1997. Utilization of phytate phosphorus and calcium as influenced by microbial phytase, cholecalciferol, and the calcium:total phosphorus ratio in broiler diets. Poultry Science 76:37-46. https://doi.org/10.1093/ps/76.1.37

R Development Core Team. 2012. R: a language and environment for statistical computing. R Foundation for Statistical Computing, Vienna. Available at: <http://www.r-project.org>. Accessed on: Nov. 26, 2012.

Rao, K. S. and Rao, B. S. N. 1983. Studies on iron chelation by phytate and the influence of other mineral ions on it. Nutrition reports international 28:771-782.

Ravindran, V.; Cowieson, A. J. and Selle, P. H. 2008. Influence of dietary electrolyte balance and microbial phytase on growth performance, nutrient utilization, and excreta quality of broiler chickens. Poultry Science 87:677-688. https://doi.org/10.3382/ps.2007-00247

Rostagno, H. S.; Albino, L. F. T.; Donzele, J. L.; Gomes, P. C.; Oliveira, R. F.; Lopes, D. C.; Ferreira, A. S. and Barreto, S. L. T. 2011. Brazilian tables for poultry and swine - Composition of feedstuffs and nutricional requirements. 3rd ed. Animal Science Department UFV, Viçosa, MG, Brazil.

Rostagno, H. S.; Albino, L. F. T.; Hannas, M. I.; Donzele, J. L.; Sakomura, N. K.; Perazzo, F. G.; Saraiva, A.; Abreu, M. L. T.; Rodrigues, P. B.; Oliveira, R. F. M.; Barreto, S. L. T. and Brito, C. O. 2017. Brazilian tables for poultry and swine - Composition of feedstuffs and nutritional requirements. 4th ed. Animal Science Department UFV, Viçosa, MG, Brazil.

Selle, P. H.; Cowieson, A. J. and Ravindran, V. 2009. Consequences of calcium interactions with phytate and phytase for poultry and pigs. Livestock Science 124:126-141. https://doi.org/10.1016/ j.livsci.2009.01.006

Selle, P. H. and Ravindran, V. 2007. Microbial phytase in poultry nutrition. Animal Feed Science and Technology 135:1-41. https://doi.org/10.1016/j.anifeedsci.2006.06.010

Tamin, N. M. and Angel, R. 2003. Phytate phosphorus hydrolysis as influenced by dietary calcium and micro-mineral source in broiler diets. Journal of Agricultural and Food Chemistry 51:4687-4693. https://doi.org/10.1021/jf034122x

Taylor, T. G. 1965. The availability of the calcium and phosphorus of plant materials for animals. Proceedings of the Nutrition Society 24:105-112.

Tran, T. T.; Hatti-Kaul, R.; Dalsgaard, S. and Yu, S. 2011. A simple and fast kinetic assay for phytases using phytic acid-protein complex as substrate. Analytical Biochemistry 410:177-184. https://doi.org/10.1016/j.ab.2010.10.034

Waldroup, P. W. 1999. Nutritional approaches to reducing phosphorus excretion by poultry. Poultry Science 78:683-691. https://doi.org/10.1093/ps/78.5.683

Walk, C. L.; Santos, T. T. and Bedford, M. R. 2014. Influence of superdoses of a novel microbial phytase on growth performance, tibia ash, and gizzard phytate and inositol in young broilers. Poultry Science 93:1172-1177. https://doi.org/10.3382/ps.2013-03571

Wise, A. 1983. Dietary factors determining the biological activities of phytase. Nutrition Abstracts and Reviews 53:791-806.

Wodzinski, R. J. and Ullah, A. H. J. 1996. Phytase. Advances in Applied Microbiology 42:263-302.

Yan, F.; Kersey, J. H.; Fritts, C. A. and Waldroup, P. W. 2006. Effect of phytase supplementation on the calcium requirement of broiler chicks. International Journal of Poultry Science 5:112-120.

Zeller, E.; Schollenberger, M.; Kühn, I. and Rodehutscord, M. 2015. Hydrolysis of phytate and formation of inositol phosphate isomers without or with supplemented phytases in different segments of the digestive tract of broilers. Journal of Nutritional Science $4: \mathrm{e} 1$. https://doi.org/10.1017/jns.2014.62 